\title{
PERBEDAAN METODE AFIRMASI DIRI DAN KONSELING UNTUK PENCEGAHAN KECEMASAN MENGHADAPI TES (TEST ANXIETY) PADA MAHASISWA KEDOKTERAN
}

\author{
Rakhmi Rafie* \\ *Fakultas Kedokteran, Universitas Malahayati \\ email rakhmirafie@yahoo.co.id
}

\begin{abstract}
DIFFERENCES METHODS OF SELF AFFIRMATION AND COUNSELING FOR ANXIETY PREVENTION FACING TESTS (TEST ANXIETY) IN MEDICAL STUDENTS AT MALAHAYATI UNIVERSITY
\end{abstract}

Background Anxiety in the face of tests (Test Anxiety (TA)) has a characteristic emotional stress that can cause problems. This incident can prevent test takers from absorbing, storing and remembering information. Given anxiety has a negative impact on the achievement of learning and physical or mental health of students, it is necessary to make certain efforts to prevent and reduce the anxiety of the main students associated with facing the exam or test. Purpose it is known that different methods of self-affirmation and counseling for the prevention of anxiety anxiety in Medical Students at Malahayati University.

MethodsThis research uses Randomized Control-Group Pretest-Posttest Design design.Population of medical students 2013 at Malahayati University Bandar Lampung.Sampel in this study were as many as 45 respondents.Analysis bivariate using Kruskal Wallis Test

The results showed that the level of anxiety level after intervention in the control group was 15.2, and in the self-affirmation group the average anxiety level was 18.07, whereas in the counseling group the average of anxiety level was 14.5.

Conclusion There is differences method of self affirmation and counseling for the prevention of test anxiety to Medical Students at Malahayati University.

Suggestion For students are expected to always think positively in facing a variety of tests, by learning to have a positive expectation, to focus on their strengths, not assessing something with a negative tendency, and distance themselves from feeling penalty and frustrating. So that confidence will be formed and achievement can be easily achieved.

Keywords: self affirmation method, counseling, test anxiety.

\begin{abstract}
ABSTRAK
Latar Belakang Kecemasan dalam menghadapi tes (Test Anxiety/TA) memiliki ciri stress emosi yang dapat menyebabkan masalah. Kejadian ini dapat menghambat peserta tes dalam menyerap, menyimpan dan mengingat informasi Mengingat kecemasan berdampak negatif terhadap pencapaian prestasi belajar dan kesehatan fisik atau mental mahasiswa, maka perlu ada upaya-upaya tertentu untuk mencegah dan mengurangi kecemasan mahasiswa utamanya terkait dengan menghadapi ujian atau tes.

Tujuan penelitian adalah diketahui perbedaan metode afirmasi diri dan konseling untuk pencegahan kecemasan menghadapi tes (test anxiety) pada Mahasiswa Kedokteran di Universitas Malahayati.

Metode Penelitian ini menggunakan desainRandomized Control-Group Pretest-Posttest Design.Populasi mahasiswa kedokteran angkatan 2013 di Universitas Malahayati Kota Bandar Lampung. Sampel dalam penelitian ini adalah sebanyak 45 responden. Analisis bivariate menggunakan uji Anova.

Hasil penelitian menunjukkanRata-rata tingkat kecemasan sesudah diberi intervensi pada kelompok kontrol adalah 15.2, dan pada kelompok afirmasi diri rata-rata tingkat kecemasan sebesar 18.07, sedangkan pada kelompok konseling rata-rata tingkat kecemasan sebesar 14.5.

Kesimpulan Ada perbedaan metode afirmasi diri dan konseling untuk pencegahan kecemasan menghadapi tes (test anxiety) pada Mahasiswa Kedokteran di Universitas Malahayati.

Saran Bagi mahasiswa diharapkan untuk selalu berpikir positif dalam menghadapi berbagai macam tes, dengan cara belajar untuk memiliki harapan yang positif, dapat memusatkan pada kekuatan yang dimiliki, tidak menilai sesuatu dengan kecenderungan negatif, dan menjauhkan diri dari perasaan menyesal dan frustasi. Sehingga kepercayaan diri akan terbentuk dan prestasi akan dapat mudah di raih.
\end{abstract}


Kata Kunci: metode afirmasi diri, konseling, test anxiety.

\section{PENDAHULUAN}

Sehat adalah kondisi normal seseorang yang merupakan hak hidupnya. Selama beberapa dekade definisi sehat masih dipertentangkan dan belum ada kata sepakat dari para ahli kesehatan maupun tokoh masyarakat dunia. Akhirnya World Health Organization (WHO) membuat definisi universal yang menyatakan bahwa sehat adalah suatu kondisi fisik, mental dan kesejahteraan sosial yang merupakan satu kesatuan dan bukan hanya bebas dari penyakit atau kecacatan (Budiman, 2006).

Mental adalah segala sesuatu yang berkaitan dengan batin dan watak manusia (Kamus Besar Bahasa Indonesia, 2014). Kesehatan mental merupakan bagian yang tidak terpisahkan dari kesehatan dan unsur utama dalam menunjang terwujudnya kualitas hidup manusia yang utuh (Siswanto, 2006). Saat ini, individu yang sehat mental dapat didefinisikan dalam dua sisi, secara negatif dengan absennya gangguan mental dan secara positif yaitu ketika hadirnya karakteristik individu sehat mental (Kartika, 2012).Maslow dan Mittlemenn menguraikan pandangannya mengenai prinsip-prinsip kesehatan mental yang menyebutnya dengan manifestation of psychological health. Maslow menyebut kondisi yang sehat secara psikologis itu dengan istilah self actualization sekaligus sebagai puncak kebutuhan dari teori hierarki kebutuhan yang disusunnya (Notosoedirjo \& Latipun, 2005).

Kegagalan dalam melakukan penyesuaian diri menyebabkan individu mengalami gangguan mental (Siswanto, 2006). Gangguan mentalmerupakan gangguan yang mempengaruhi kognisi, emosi,kontrol perilaku dan secara substansial mempengaruhi baik kemampuan anakanak untuk belajar serta kemampuan orang dewasa untukberfungsi secara efektif baik di dalam keluarga, di lingkungan kerja, maupun di masyarakat secara luas (Hyman, 2000).

Sekitar 450 juta orang yang hidup saat ini menderita gangguan mental, menurut perkiraan yang diberikan dalam Laporan Kesehatan Dunia WHO 2001. Satu dari empat orang akan terpengaruh oleh gangguan mental pada beberapa tahap hidupnya (WHO 2002).Di Indonesia, berdasarkan Data Riskesdas tahun 2007, diketahui bahwa prevalensi gangguan mental emosional seperti gangguan kecemasan dan depresi sebesar $11,6 \%$ dari populasi orang dewasa. Berarti dengan jumlah populasi orang dewasa Indonesia lebih kurang 150.000 .000 ada 1.740 .000 orang saat ini mengalami gangguan mental emosional (Depkes,
2007). Kecemasan menduduki urutan ke empat gejala yang paling sering dimiliki oleh orang yang mengalami gangguan mental emosional (Sri Idaiani, Suhardi, Antonius Yudi Kristanto, 2009).

Kecemasan, kegugupan atau agitasi yang kita alami, seringkali mengenai sesuatu yang akan terjadi, adalah bagian alami dari kehidupan. pengalaman, sering tentang sesuatu yang akan terjadi, adalah bagian alami dari kehidupan. Kecemasan adalah emosi manusia yang penting dan berguna; hal ini terkait dengan aktivasi sistem saraf simpatik dan respon fisiologis dan perilaku yang membantu melindungi kita dari bahaya (Kessler, Chiu, Demler, \& Walters, 2005). Akan tetapi kecemasan yang berlebihan dapat melemahkan, dan setiap tahun jutaan orang menderita gangguan kecemasan, yaitu gangguan psikologis yang ditandai dengan ketakutan yang irrasional, kerapkali dengan objek dan situasi sehari-hari (Kessler, Chiu, Demler, \& Walters, 2005). Seseorang akan menderita gangguan cemas manakala yang bersangkutan tidak mampu mengatasi stresor psikososial yang dihadapinya (Hawari, 2001).

Kecemasan dalam menghadapi tes (Test Anxiety (TA)) memiliki ciri stress emosi yang dapat menyebabkan masalah. Kejadian ini dapat menghambat peserta tes dalam menyerap, menyimpan dan mengingat informasi. Kecemasan menimbulkan semacam "bising" di otak yang menghambat pemahaman atau analisa. Penelitian telah menunjukan dengan memberikan peserta tes alat dan strategi yang membangun baik emosional maupun keterampilan dan kebiasaan fisik yang sehat ketika menghadapi tes dapat mencegah terjadinya kecemasan menghadapi tes (Gilbert dan Miller, 2014).

Pikiran dan sikap hati negatif menyebabkan blocking energy seperti rasa kuatir, takut, marah, sedih, dan sikap kepura-puraan yang sejatinya menghalangi manusia menikmati kesehatan holistik atau kesehatan paripurna, yaitu kesehatan paripurna, yaitu kesehatan sempurna dalam aspek fisik, mental emosional, estetika, sosial, ekonomi, dan spiritual (Mardihusodo, 2012).

Kejadian ini dapat dicegah dengan pendekatan promosi kesehatan mental yakni upaya meningkatkan status kesehatan mental individu maupun masyarakat. Institusi pendidikan merupakan salah satu bagian penting dalam dalam promosi kesehatan, dikarenakan memiliki proporsi populasi yang cukup besar. Bagian dari pertumbuhan anak didik adalah pengambilan keputusan, akan tetapi yang jadi permasalahan ketika mereka tidak sadar 
dapat menjadi faktor resiko dari hal tersebut ( Jennie \& Jane, 2009). Salah satu karakteristik yang banyak dijumpai pada diri mahasiswa adalah secara psikologis belum siap untuk melaksanakan proses pembelajaran pendidikan tinggi (DIKTI, 2003). Berdasarkan data dari wawancara peneliti terhadap 15 mahasiswa pembimbingan akademik mengatakan cemas menghadapi ujian yang mengakibatkan beberapa diantaranya sampai tidak mampu menganalisa kasus dengan baik.

Secara umum faktor-faktor yang menyebabkan timbulnya kecemasan adalah faktor internal dan faktor eksternal, faktor internal meliputi tingkat religiusitas yang rendah, rasa pesimis, takut gagal, pengalaman negatif masa lalu, dan pikiran yang tidak rasional. Sementara faktor eksternal seperti kurangnya dukungan sosial ( Ghufron \& Risnawati 2010). Emosi ini seringkali tidak mampu dirasionalkan oleh pikiran sadar, pikiran bawah sadar biasanya lebih responsif secara emosional terhadap suatu hal (Wirawandha, 2014).

Banyak penelitian telah menggunakan teori afirmasi untuk mengatasi berbagai berbagai fenomena psikologis, termasuk pengolahan informasi bias, atribusi kausal, disonansi kognitif, prasangka dan stereotip, stres dan memamah biak (Sherman \& Cohen 2006). Selain efek psikis afirmasi juga terbukti secara fisik, seperti dapat menurunkan kadar kortisol pada individu yang mengalami stress (Creswell et al, 2005) Hasil penelitian mengungkapkan bahwa intervensi psikologis diriafirmasi-memfasilitasi hilangnya kontrol diri. Percobaan 1 dan 2 ditemukan efek menguntungkan dari afirmasi pada pengendalian diri dalam keadaan habis. Percobaan 3 dan 4 menyatakan bahwa penegasan diri meningkatkan kontrol diri dengan mempromosikan tingkat yang lebih tinggi (vs tingkat yang lebih rendah) dari construal mental. Oleh karena itu afirmasi memegang janji sebagai strategi mental yang mengurangi kemungkinan kegagalan pengendalian diri (Schemeichel \& Vohs 2009).

Mengingat kecemasan berdampak negatif terhadap pencapaian prestasi belajar dan kesehatan fisik atau mental mahasiswa, maka perlu ada upayaupaya tertentu untuk mencegah dan mengurangi kecemasan mahasiswa utamanya terkait dengan menghadapi ujian atau tes. Plhak universitas perlu menyediakan layanan konselingbagi siswa yang mengalami kecemasan mengikuti tes atau ujian.Layanan bimbingan dan konseling dapat dijadikan sebagai kekuatan inti di sekolah guna mencegah dan mengatasi kecemasan mahasiswa. Konseling rasional emotif (KRE)merupakan salah satu pendekatan konseling yang menawarkan dimensi kognitif dan menantang klien menguji rasionalitasnya. Menilai dari beberapa uraian tersebut, maka KRE dipilih untuk membantu mahasiswa dalam menurunkan tingkat kecemasan dalam menghadapi ujian atau tes.

Konseling dengan pendekatan rasional emotif telah digunakan secara meluas untuk mengatasi atau menghilangkan berbagai gangguan emosional yang dapat merusak diri, seperti benci, takut, cemas, was-was sebagai akibat berpikir yang irasional dan melatih menghadapi kenyataan secara rasional. Terdapat berbagai teknik yang dipergunakan dalam $\mathrm{KRE}$, diantaranya adalah disentisasi sistematis, pengkondisian instrumental, relaksasi dan modeling. Dalam penelitian ini peneliti akan mempergunakan teknik relaksasi.

Tujuan penelitian ini adalah Diketahui perbedaan metode afirmasi diri dan konseling untuk pencegahan kecemasan menghadapi tes (test anxiety) pada Mahasiswa Kedokteran di Universitas Malahayati

\section{METODE PENELITIAN}

Jenis Penelitian ini adalah penelitian yang bersifat kuantitatif analitik eksperimen. Penelitian ini dilaksanakan pada bulan Juni 2017 di Fakultas Kedokteran Universitas Malahyati Bandar Lampung.Penelitian ini menggunakan desainRandomized Control-Group Pretest-Posttest Design yaitu eksperimen dengan satu perlakuan yaitu afirmasi diri dan sebuah kontrol.Populasi mahasiswa kedokteranangkatan 2013 di Universitas Malahayati Kota Bandar Lampung. Sehingga sampel yang digunakan dalam penelitian ini sejumlah 15 responden untuk masing-masing kelompok.Variabel yang digunakan dalam penelitian ini adalah variabel independent(Afirmasi Diri)dan variabel dependent (kecemasan menghadapi tes/ test anxiety).

Pengumpulan data dilakukan dengan menggunakan kuesioner tentang kecemasan dengan menggunakan HARS yang dilakukan sebelum metode afirmasi diri, kemudian peneliti memberikan metode afirmasi diri yang akan dilakukan kemudian dilakukan pengukuran kembali terhadap tingkat kecemasanmahasiswa setelah metode afirmasi diri. Cara pengukuran kecemasan dengan menggunakan HARS yaitu: masing-masing kelompok gejala diberi penilaian angka (score) antara $0-4$, yang artinya adalah: Nilai $0=$ tidak ada gejala (keluhan), 1 = gejala ringan, 2 = gejala sedang, 3 = gejala berat, $4=$ gejala berat sekali. Masing-masing nilai angka dari ke 14 kelompok tersebut dijumlahkan.

Analisa bivariat dilakukan untuk mengetahui perbedaan metode afirmasi diri dan konseling untuk pencegahan kecemasan menghadapi tes (test 
anxiety) pada Mahasiswa Kedokteran di Universitas Malahayati. Prosedur yang digunakan dalam analisis ANOVA ini adalah prosedur One-Way ANOVA

\section{HASIL PENELITIAN}

Bagian ini akan disajikan deskripsi data hasil penelitian terhadap variabel-variabel penelitian. Data hasil penelitian berupa skor yang diambil dari tes terhadap responden sebagai dasar untuk menganalisis lebih lanjut penelitian ini.

\section{Analisis Univariat}

\section{Kecemasan Pre Test}

Tabel dibawah didapatkan bahwa rata-rata tingkat kecemasan sebelum diberi intervensi pada kelompok control adalah 17.27, dengan standar deviasi 1.94, tingkat kecemasan terendah adalah 15 dan tertinggi 21 , dan pada kelompok afirmasi diri rata-rata tingkat kecemasan sebesar 20.73 , dengan standar deviasi 4.45 , tingkat kecemasan terendah adalah 15 dan tertinggi 26, sedangkan pada kelompok konseling rata-rata tingkat kecemasan sebesar 18.2, dengan standar deviasi 2.65, tingkat kecemasan terendah adalah 16 dan tertinggi 26 .

Tabel 1.

Distribusi Kecemasan Sebelum Intervensi pada Mahasiswa Kedokteran di Universitas Malahayati

\begin{tabular}{cccc}
\hline \multirow{2}{*}{ Intervensi } & \multicolumn{3}{c}{ Skor Kecemasan Pretest } \\
\cline { 2 - 4 } & Mean & Sdt Dev & Min-Max \\
\hline Kontrol & 17.27 & 1.94 & $15-21$ \\
Afirmasi Diri & 20.73 & 4.45 & $15-26$ \\
Konseling & 18.2 & 2.65 & $16-26$ \\
\hline
\end{tabular}

Kecemasan Post Test

Tabel 2.

Distribusi Kecemasan Sesudah Intervensi pada Mahasiswa Kedokteran di Universitas Malahayati

\begin{tabular}{cccc}
\hline \multirow{2}{*}{ Intervensi } & \multicolumn{3}{c}{ Skor Kecemasan Posttest } \\
\cline { 2 - 4 } & Mean & Sdt Dev & Min-Max \\
\hline Kontrol & 15.2 & 2.14 & $12-19$ \\
Afirmasi Diri & 18.07 & 3.92 & $12-24$ \\
Konseling & 14.5 & 2.67 & $12-22$ \\
\hline
\end{tabular}

Tabel diatas didapatkan bahwa rata-rata tingkat kecemasan sesudah diberi intervensi pada kelompok kontrol adalah 15.2, dengan standar deviasi 2.14, tingkat kecemasan terendah adalah 12 dan tertinggi 19 , dan pada kelompok afirmasi diri rata-rata tingkat kecemasan sebesar 18.07, dengan standar deviasi 3.92, tingkat kecemasan terendah adalah 12 dan tertinggi 24, sedangkan pada kelompok konseling rata-rata tingkat kecemasan sebesar 14.5, dengan standar deviasi 2.67, tingkat kecemasan terendah adalah 12 dan tertinggi 22 .

\section{Analisis Multivariat}

Berdasarkan hasil uji hipotesis dengan bantuan program SPSS diterangkan dalam tabel 3 . Hasil tabel 3 diketahui bahwa mean rank untuk kelompok kontrol sebesar 14,9, kelompok afirmasi diri sebesar 21,77 dan kelompok konseling 32,33. Dari hasil uji statistik di atas $p$-value $=0,001$, maka dapat disimpulkan ada perbedaan antara metode afirmasi diri dan konseling dan kontrol untuk pencegahan kecemasan menghadapi tes (test anxiety) pada Mahasiswa Kedokteran di Universitas Malahayati.

ITabel 3

Perbedaan Metode Afirmasi Diri Dan Konseling Untuk Pencegahan Kecemasan Menghadapi Tes (Test Anxiety) pada Mahasiswa Kedokteran di Universitas Malahayati

\begin{tabular}{lccc}
\hline \multicolumn{1}{c}{ Kelompok } & N & Mean Rank & P Value \\
\hline Kontrol & 15 & 14.9 & 0,001 \\
Afirmasi Diri & 15 & 21.77 & \\
Konseling & 15 & 32.33 & \\
\hline
\end{tabular}




\section{PEMBAHASAN}

Hasil penelitian menunjukkan ada perbedaan metode afirmasi diri dan konseling untuk pencegahan kecemasan menghadapi tes (test anxiety) pada Mahasiswa Kedokteran di Universitas Malahayati.

Hasil signifikan pada penurunan kecemasan menghadapi tesMahasiswa sesuai dengan Peale (2006) yangmenyatakan bahwa berpikir positif bagi remajabisa menumbuhkan dan memaksimalkan energi,memberikan keyakinan dalam merespon stimulus dan harapan untuk mencapai tujuan hidupnya.

Aspek ketiga dalam kecemasan berupa aspekfisik seperti diaphoresis (keluar keringatbanyak), kulit dingin, lembab, urat nadi cepatdan arrhythmias (hilangnya irama/irama tidakteratur), muka menjadi merah dan muka pucat,hyperreflexia (refleks yang berlebihan), danfisik menggigil, mudah terkejut dan gelisahyang dipertahankan dalam pola pikir siswadapat semakin menguat apabila pemikirannyaselakin negatif. Beck (dalam Russell, 2003)mengatakan bahwa seluruh suasana hati dibentuk oleh pikiran/kognisi seseorang. Individumerasakan yang dikerjakan saat ini karenapikiran yang dimiliki sekarang.Keempat aspek dalam berpikir positif yangsaling berkesinambungan secara signifikanmemberikan kemampuan pada siswa untukmengelola kecemasan menjelang tes menjadisebuah kompensasi positif. Hal ini dapat membawa mahasiswa menggali kemampuan dan memperoleh tujuannya yaitu melewati tes denganenergi-energi positif tanpa dibebani pemikiran-pemikiran yang negatif. Harapanya kedepannyasiswa dapat memperoleh hasil terbaiknya dalam tes nasional April mendatang. Beck (dalamRussell, 2003) mengatakan bahwa pikiran-pikiran yang didominasi oleh negativitas akanmembuat seseorang merasa tertekan.

Hasil penelitian ini membuktikan kecemasandapat diturunkan dengan proses berpikir positif.Hal ini sesuai dengan teori bahwa berpikirsecara umum adalah suatu cara penyesuaianindividu terhadap lingkungannya, oleh karenaitu dapatlah dikemukakan bahwa orang ituberpikir bila menghadapi permasalahan ataupersoalan (Walgito, 1990). Kecemasan merupakan suatu masalah. Salah satu penyelesaiaannyaadalah dengan berpikir (Gazali, 1980). Perasaancemas terbukti merupakan manifestasi apa yangdipikirkan seseorang. Perasaan menentukanperilaku yang muncul sesuai dengan apa yangdiperintahkan oleh pikiran. Sesuai penelitian iniperasaan kecemasan menghadapi tes diturunkan menggunakan pelatihan berpikir positif.Penelitian berpikir positif pada penelitian initerbukti mampu menurunkan kecemasan menghadapi tes pada Mahasiswa. Hal ini sesuaidengan Mckay (2002) menjelaskan bahwa seseorang dapat memilih perasaan dengan pikirannya. Perubahan pola pikir yang dilakukanmempengaruhi perasaan subjek sehingga menyebabkan perubahan kecemasan menghadapi tes pada subjek kelompok eksperimen. Kajianempirik yang menunjukkan bahwa pelatihanberpikir positif berpengaruh terhadap penurunan kecemasan siswa menjelang tes terbuktisecara signifikan. Artinya, dengan pelatihanberpikir positif pada Mahasiswa maka mahasiswa mengalami penurunan kecemasan dalam menghadapi tes.

Penelitian ini hanya mampumengontrol perubahan perasaan subjek selamaproses penelitian berdasarkan hasil perubahanskor dan evaluasi. Kelemahan dalam penelitianini juga karena waktu penelitian yang hanyasatu hari. Hal ini menyebabkan peneliti tidakmampu melakukan kontrol secala kontinyupada subjek untuk waktu yang lainnya. Perubahan yang positif pada kelompok eksperimendapat dilihat pada selisih skor sebelum dansesudah yang mengalami penurunan secaramenyeluruh. Hal ini dapat dilihat pada masingmasing skor sebelum dan sesudah mengalamipenurunan. Sementara pada kelompok control penyebarannya tidak merata ada yang naik danada yang turun pada masing-masing total skorsubjek sebelum dan sesudah. Subjek mengalamiperubahan skor yang menurun secara signifikansehingga mengalami penurunan kecemasan menghadapi tes (test anxiety).Sementara pada kelompok kontrol justru mengalami perubahan yang tidak merata denganselisih skor yang bervariasi atau ada skor positifdan negatif dan perubahan yang terjadi antaraskor pre tes dan pos tes tidak signifikan.

Subjek penelitian secara konstan diajak berpikir dan membayangkan, sehingga individumempunyai pikiran otomatis setiap saat. Pikiranotomatis yang muncul berupa pikiranpikiranpositif dikuatkan melalui afirmasi diri sepertikecemasan menghadapi tes (test anxiety)diturunkan dengan hal positif sesuai apa yang individu yakini.Apabila individu percaya sesuatu mungkinterjadi, maka individu tersebut akan menciptakan perilaku yang mendukung kepercayaanini. Sebaliknya, jika individu menganggap bahwa menghilangkan suatu pola kebiasaan adalahhal yang sulit dilakukan, kemungkinan itulahyang akan terjadi, namun bila 
individu yakinbahwa dirinya mampu berubah dan benar-benarmelakukan perubahan, maka akan menguatkankeyakinan positif yang baru hingga individumempercayai bahwa dirinya dapat meninggalkan kebiasaan. Hal ini membuktikan pernyataanbahwa seseorang yang menggunakan pola berpikir positif dalam menghadapi permasalahanakan mempunyai ciri optimis dalam menghadapi permasalahannya, mempunyai penghargaan yang tinggi terhadap dirinya, dan mempercayai bahwa dunia merupakan tempat yangrasional dan terprediksi (Goodhart, 1985).

Sedangkan seseorang yang menggunakan polaberpikir negatif dalam menghadapi permasalahan akan mempunyai ciri sebagai berikut:pesimis dan putus asa dalam menghadapi permasalahannya, memandang negatif dunia, diridan masa depannya (Beck, 1985; Goodhart,1985). Penelitian Cridder (dalam Goodhart, 1985) menemukan bahwa dengan memusatkanperhatian pada sisi positif dari suatu keadaanyang sedang dihadapi, akan membuat seseoranglebih mampu mempertahankan emosi positifnyadan mencegah emosi negatif, serta membantudalam menghadapi situasi yang mengancap danmenimbulkan kecemasan. Sikap positif terhadap kecemasan akan meningkatakan kesehatan mental, dan pada saatnya akan dapatmenahan atau menghadapi kecemasan yangmuncul dalam kehidupan sehari-hari. Begitupula yang diungkapkan dalam sebuah penelitianmengenai strategi coping terhadap kecemasanmenghadapi tes, terbukti bahwa berpikir positifmerupakan salah satu strategi untuk menyesuaikan diri terhadap kecemasan dalam menghadapi UN (Kondo, 1997).

$$
\text { Pelatihan berpikir positif sebagai }
$$

kegiatanyang dilaksanakan secara sistematis denganmengacu pada panduan yang dikembangkandari teori yang ada terbukti dapat mengarahkansiswa kelas untuk menurunkan kecemasanmenghadapi UN. Aspek pertama dalam kecemasan adalah aspek psikologis berupa apprehension (keprihatinan/ kecemasan pada masadepan), keraguan ketakutan dan antisipasikemalangan, perasaan kiamat atau panic, hipervigilan (kecenderungan untuk bereaksi berlebihan terhadap stress yang tidak begitu berat),lekas marah, lelah, insomnia (kesulitan untuktidur), kecenderungan mengalami kecelakaan,derealisasi (dunia tampak aneh) dan depersonalisasi (merasa diri sendiri tidak nyata) dankesulitan dalam memusatkan pikiran. Hal iniakan mengganggu proses berpikir para mahasiswayang akan menghadapi tes. Positif expectation yang diarahkan untukmengubah pola pikir negatif yang menghasilkankecemasan mampu menjadi salah satu alternative dari serangkaian pemikiran negatif terhadap tes. Mahasiswa mampu menentukan secara objektifharapan-harapan yang positif dari dalam dirinyasehingga berusaha lebih baik untuk meraihnyadengan mempertimbangkan kemampuan diri(self affirmation) secara objektif.

Proses pelatihan berpikir positif terbuktimendukung kemampuan mengelola pemikirandengan yaitu sebuah aktifitas pikiran denganmenyampaikan respon sebuah stimulus melaluipernyataan yang lebih menggambarkan keadaandari pada menilai keadaan. Hal ini sepertidijelaskan oleh Beck dalam Russell (2003) yangmenyatakan bahwa terdapat hubungan yangkuat antara emosi, pikiran dan perilaku. Emosidan perilaku terbentuk oleh suatu peristiwayang disebabkan oleh pemikiran seseorangterhadap peristiwa yang dialaminya. Hal inimenegaskan bahwa kunci utama dari emosi danperilaku adalah bagaimana pemikiran individuterhadap peristiwa yang dialami. Pernyataan-pernyataan yang tidak menilai secara subjektif(non judgement talking) akan menjadi pengganti pada saat individu cenderung memberikan pernyataan atau penilaian yang negatif dengan melihat keadaan sebenarnya dan berpikir lebih realistis. Mahasiswa dapatmengelola pemikiran positifnya sehingga dapatberadaptasi dengan kenyataan yang ada (realityadaptation). Hal ini akan membentuk sebuahpola pikir yang sinergis untuk menunjukkankemampuan optimal seorang siswa tanpa merasa harus selalu tunduk karena dominasi kecemasan yang ada di dalam dirinya. Mahasiswa secara objektif dapat menempatkan dimanadirinya harus menaati ketentuan yang ada tanpamerasa takut dengan tes.

Aspek kedua dalam kecemasan adalah aspeksomatic yang ditandai dengan kondisi sakitkepala, pusing dan berkunang-kunang, jantungberdebar dan dada sakit, mengganggu perut dandiare, sering buang air kecil, bengkak dikerongkongan, tensi bergerak atau kegelisahan,nafas pendek, paresthesias (perasaanperasaankulit yang abnormal seperti gatal-gatal, menu-suk-nusuk atau seperti terbakar). Hal ini munculsemakin kuat dan mengganggu aktifitas siswa menjelang tes ketika siswa mengelola pemikirannya secara negatif. Pelatihan berpikirpositif dengan perlakuan yang sistematis akanmembawa Mahasiswa meyakini kemampuan dan kekuatan dirinya (Self Affirmation). Siswa dapat memusatkan perhatian pada kekuatan diri dan melihat diri secara positif terhadap tes dan menggunakannya secara 
maksimaluntuk mencapai tujuanya yaitu dapat lulus tes dengan nilai maksimal. Positif expectationsebagai salah satu ranah dalam berpikir positifdigunakan untuk mengarahkan Mahasiswa melakukan sesuatu dengan lebih memusatkan perhatian pada kesuksesan, optimisme,pemecahan masalah sehingga perasaan kurangkompeten akan dikelola dalam proses pemikiranyang lebih positif. Siswa dapat menjauhkan diridari perasaan takut akan kegagalan. Tes tidaklagi dijadikan penghalang, siswa diharapkanmampu memperhatikan hal-hal positif danmenilai secara positif apa yang terjadi dan adadi dalam dirinya. Aktivasi non judgementtalking apabila siswa memberikan pernyataanatau penilaian yang negatif terkait tes akanmengelola perasaan yang muncul ke dalam halyang lebih positif.

Dalam penelitian ini diketahui pada kelompok konseling rata-rata tingkat kecemasan sebesar 14.5, dengan standar deviasi 2.67, tingkat kecemasan terendah adalah 12 dan tertinggi 22. Hal ini disebabkan karena adanya penurunan terhadap kualitas konseling yang dilakukan, mengingat pemberian konseling hanya dilakukan satu hari, dan dilakukan oleh satu orang konselor, sehingga pada responden yang awal mendapatkan konseling, konselor memberikan arahan dengan baik, namun setelah responden lebih dari 10 orang konseling yang diberikan kurang optimal karena konselor mulai merasa lelah sehingga tidak fokus terhadap bahasan yang diberikan, oleh karena itu pada penelitian selanjutnya untuk membatasi jumlah sampel perharinya.

\section{KESIMPULAN}

Rata-rata tingkat kecemasan sesudah diberi intervensi pada kelompok kontrol adalah 15.2, dengan standar deviasi 2.14, tingkat kecemasan terendah adalah 12 dan tertinggi 19, dan pada kelompok afirmasi diri rata-rata tingkat kecemasan sebesar 18.07, dengan standar deviasi 3.92, tingkat kecemasan terendah adalah 12 dan tertinggi 24, sedangkan pada kelompok konseling rata-rata tingkat kecemasan sebesar 14.5 , dengan standar deviasi 2.67, tingkat kecemasan terendah adalah 12 dan tertinggi 22. Ada perbedaan metode afirmasi diri dan konseling untuk pencegahan kecemasan menghadapi tes (test anxiety) pada Mahasiswa Kedokteran di Universitas Malahayati.

\section{SARAN}

Bagi mahasiswa diharapkan untuk selalu berpikir positif dalam menghadapi berbagai macam tes, dengan cara belajar untuk memiliki harapan yang positif, dapat memusatkan pada kekuatan yang dimiliki, tidak menilai sesuatu dengan kecenderungan negatif, dan menjauhkan diri dari perasaan menyesal dan frustasi. Sehingga kepercayaan diri akan terbentuk dan prestasi akan dapat mudah di raih..

\section{DAFTAR PUSTAKA}

Badan Penelitian dan Pengembangan Kesehatan (2007). Riset Riset Kesehatan Dasar. Jakarta

Cohen, G. L., Sherman, D. K., Bastardi, A., McGoey, M., Hsu, A., \& Ross, L. (2007). Bridging the partisan divide:Self-affirmation reduces ideological closed-mindedness and inflexibility in negotiation. Journal of Personality and SocialPsychology, 93, 415430

Departement of Mental Health and Substance Dependence, WHO (2002). Prevention and Promotion in Mental Health. Geneva: WHO Library

Gable, S. L., Haidt, J. (2005). What (and Why) is Positive Psychology?. Review ofGeneral Psychology, Vol.9 (2), 103-110

Goodhart, D. 1985. Some Psychological Effect of Positive and Negative Thinkingabout Stressful Event Outcomes: Was Pollyana Right. Journal of Personalityand Social Psychology, 48, 216-232

http://kesehatan.kompasiana.com/kejiwaan/2013/12 /25/peningkatan-kesehatan-mental-usiamuda-dengan-media-internet-619639.html

Hyman, S. E. (2000). "The Genetics of Mental Illness: Implications for Practice." Bulletin of the World Health Organization

Kessler, R., Chiu, W., Demler, O., \& Walters, E. (2005). Prevalence, severity, and comorbidity of 12-month DSM-IV disorders in the National Comorbidity Survey Replication. Archives of General Psychiatry

Kondo, D. S. (1997). Strategies for Coping withTest Anxiety. www.e-jurnal.com Vol. 10, p203-215. Diakses 17 Desember 2016

Madani (2013) diakses dari Mardihusodo, S. Emotional Freedom Technique (EFT). Jakarta : NQ Publishing

Mckay, G. (2002). How You Feel is Up To You.Jakarta: PT. Gramedia Widia Saranalndonesia.

Naidoo dan Wills. (2009). Foundations for Health Promotion. USA: Elsevier

Sri, Suhardi, Antonius. (2010). Analisa Gangguan Mental Emosional Penduduk Indonesia, Majalah Kedokteran Indonesia, 59(10)

Vohs, K.D., Baumeister, R.F., Schmeichel, B.J., Twenge, J.M., Nelson, N.M.,Tice, D.M. 2008. 
Making choices impairs subsequent selfcontrol: alimited-resource account of decision making, self-regulation, and activeinitiative. Journal of Personality and Social Psychology,
Vol. 94, No. 5,883-898 DOI: 10.1037/00223514.94.5.883.

Diakses darihttp://psycnet.apa.org/index.cfm?fa=buy. optionToBuy\&id=2008-04567-010 